Abstracta Iranica Iranica

Revue bibliographique pour le domaine irano-aryen

Volume 28 | 2007

Comptes rendus des publications de 2005

\title{
Géopolitique du Nouvel Afghanistan. Paris, Ellipses, 2005, 100 p.
}

\section{Anicée Van Engeland}

\section{(2) OpenEdition}

1 Journals

\section{Édition électronique}

URL : http://journals.openedition.org/abstractairanica/19731

DOI : 10.4000/abstractairanica. 19731

ISSN : 1961-960X

Éditeur :

CNRS (UMR 7528 Mondes iraniens et indiens), Éditions de l'IFRI

\section{Édition imprimée}

Date de publication : 15 mai 2007

ISSN : 0240-8910

\section{Référence électronique}

Anicée Van Engeland, « Géopolitique du Nouvel Afghanistan. Paris, Ellipses, 2005, 100 p. », Abstracta Iranica [En ligne], Volume 28 | 2007, document 459, mis en ligne le 18 septembre 2007, consulté le 25 septembre 2020. URL : http://journals.openedition.org/abstractairanica/19731 ; DOI : https://doi.org/ 10.4000/abstractairanica.19731

Ce document a été généré automatiquement le 25 septembre 2020.

Tous droits réservés 


\title{
Géopolitique du Nouvel
} Afghanistan. Paris, Ellipses, 2005, $100 \mathrm{p}$.

\author{
Anicée Van Engeland
}

Cet ouvrage couvre les périodes de cristallisation étatique afghanes depuis 1747, ainsi que les échecs d'étatisation. L'A. fait ensuite le point sur la tentative de construction de l'État afghan depuis l'invasion américaine: s'il y a des progrès réels, le pays reste à construire tant les ethnies qui le peuplent sont variées et tant les menaces sont nombreuses. À cela s'ajoute la menace islamique venue du Pakistan. La question est de savoir si l'Afghanistan peut exister sans le soutien occidental. Et comment effacer les lignes de fractures géographiques et identitaires profondes pour constituer une nation?

\section{INDEX}

Thèmes : 13.2. Afghanistan

\section{AUTEURS}

ANICÉE VAN ENGELAND

Paris 